and inspiration, calls in her coworker, Jack Frost, and creates a masterpiece of beauty and ingenuity.

Such was a morning, one day this winter. The entire countryside was touched with the magic of heavy hoar frost.

The nude poplar trees were transformed in new, sparkling gowns. A beautiful, exotic jungle of white fronds, tufts, and lacy foliage shimmered and glistened where, only the evening before, had been an uninteresting tangle of willow bushes and underbrush. Grass and small shrubs flourished in sprays of tinsel. Strangely pronged and nubbined as the frost collected on their spines, rose bushes offered their red haws like a display of deliciously frosted bon-bons. Paralleling the road ran a line of jewell-encrusted staffs strung with delicately wrought garlands, a series of intricate knots masking the sharp barbs of the wire fence. A big granite boulder stood up proudly, its weather-scarred sides softened and scintillating, like a throne for some snow queen to hold court from.

Lithe, graceful, a weasel poked inquisitively about a group of small, gem-studded pyramids, pocket gopher mounds. From a clump of frostplumed pigweed a flock of Redpolls twittered, patterning the snow with myriads of tiny tracks. Dee! Dee! a Chickadee sang cheerfully, and as he flitted among the branches of a birch tree he loosened showers of twinkling diamonds. A coyote's trail along the edge of a meadow was filled in with shiny particles, and from an open sidehill, the dark mouth of an old groundhog den showed a throat fringed and whiskered in white.

The sun heightened, a slight breeze trembled through the fairyland of diamond and crystal and sparkling white. Soon, this glistening, jewellhung tapestry of fragile lace and exquisite carvings would vanish. But the beauty of it would be a thing to remember, to marvel at, and to be looked forward to, again.

\section{The March of Days}

\section{Elizabeth Cruickshank, Regina}

"There is no greater eloquence I know Than sun and frost setting the day aglow."

So many of these eloquent days this mild winter. On one we drove to Lumsden to find "a silent loveliness, on hill and wood and field." Ridges in the stubble fields made rhythmic patterns of gold and white, the fields made merry by flocks of snow buntings rising and falling like waves. We saw no other birds. Tracks and tunnels led from the stooks, some short leaps, as if made with dancing feet, but the fan-shaped impressions where tails were used as brakes, were mute evidence of sudden changes in direction. How dangerously deermice live.

Cactus spines were soft now so the dogs walked in comfort on the hill. Judy showed us the very cactus that kept her wee bantam chick impaled. a whole July day.

On how many days has our yard been a fairyland, when even Sparrows made a charming picture in the maple, frost petals falling at their feet as they flew down for breakfast; days when eyerywhere was gleaming crystals or glistening frost; when, by the creek, dock made "silver candles straight;" when grass crunched underfoot; when frost filagree transformed every humble weed.

Kingsley has urged us to "treat beauty wherever we see it as a wayside sacrament." A clump of lovely pale green western dock, with its dense fruiting heads, provided the "charmed draught, the cup of blessing" on one silver and gold and blue day.

How many times muskrat burrow entrances have been unbelievably beautiful, wreathed exquisitely with diamonds and stars.

The one surprise for us this winter on the golf course was a Ring-necked Pheasant's arrow track on fresh shallow snow.

In this small territory we have stored treasurable memories of the beauty and mystery of the varied dramas of life in all seasons. 